\title{
Risk Assessment on Trace Metals in Groundwater and Springs in Urban Environment of Zanzibar Island
}

\author{
Abdul Ali Juma Mohamed*, Sara Abdalla Khamis, Haji Mwevura, Miza Ali Kombo, \\ Said Suleiman Bakari
}

Department of Natural Sciences, State University of Zanzibar (SUZA), Zanzibar, Tanzania

Email address:

jumabdull@yahoo.com (A. A. J. Mohamed)

${ }^{*}$ Corresponding author

\section{To cite this article:}

Abdul Ali Juma Mohamed, Sara Abdalla Khamis, Haji Mwevura, Miza Ali Kombo, Said Suleiman Bakari. Risk Assessment on Trace Metals in Groundwater and Springs in Urban Environment of Zanzibar Island. International Journal of Environmental Monitoring and Analysis. Vol. 4, No. 2, 2016, pp. 45-55. doi: 10.11648/j.ijema.20160402.12

Received: March 13, 2016; Accepted: March 22, 2016; Published: April 1, 2016

\begin{abstract}
Urban-west region is the most highly populated region of Zanzibar. More than half of the Zanzibar populations reside at this region. Groundwater is the main resource of drinking water in this area, and currently there is no drinking water treatment plant; hence, the suitability and appropriateness of groundwater resources for drinking and other domestic uses is of public and scientific concern. In this study, groundwater samples were collected from 30 sites in urban areas of Zanzibar Island in December 2012. Measurements, and investigation of the levels of trace metals in water including $\mathrm{Cd}, \mathrm{Co}, \mathrm{Cr}(\mathrm{III}), \mathrm{Cu}, \mathrm{Fe}$, $\mathrm{Li}, \mathrm{Mn}, \mathrm{Mo}, \mathrm{Sb}, \mathrm{Se}, \mathrm{Ti}$, and $\mathrm{Zn}$ were measured in thirty locations in Zanzibar urban west region using Inductively Coupled Plasma Emission Spectroscopy (ICP-OES). The paper also highlights and depicts the estimate of the degree of metal contamination $\left(\mathrm{C}_{\mathrm{d}}\right)$, hazard quotient which yields hazard index $(\mathrm{HI})$, heavy metal evaluation index (HEI), and heavy metal pollution index (HPI). Using the four heavy metals $(\mathrm{Cd}, \mathrm{Zn}, \mathrm{Cu}$, and $\mathrm{Fe})$, the degree of contamination $\left(\mathrm{C}_{\mathrm{d}}\right)$ in all water sources were less than 1, thus they fall in to the category of low degree of contamination. The general trend of the average daily dose (ADD) of $\mathrm{Zn}, \mathrm{Cu}, \mathrm{Fe}$, and $\mathrm{Cd}$ in water sources was $\mathrm{Zn}>\mathrm{Cu}>\mathrm{Fe}>\mathrm{Cd}$. As the severity of metal toxicity is governed by several factors, such as dose, nutrition, age, and even life style. Therefore, this trend might not guarantee the absence of human health risk. Generally, from risk assessment on trace metals using risk indices $\left(\mathrm{C}_{\mathrm{d}}\right.$, HPI, HI and HEI), the analyzed water sources might not be at the alarming health risk. However, due to an increasing level of environmental pollution, water sources might be potential sink of contaminants; this is significant reason that makes the treatment of drinking water and monitoring implementation inevitable.
\end{abstract}

Keywords: Zanzibar, Degree of Contamination, Risk Assessment, Health Risk, Environmental Pollution

\section{Introduction}

Water is an essential compound for all forms of life in the Earth planet. Springs and groundwater are the two main sources of water used for domestic and other social purposes in Zanzibar. The exploitation of water from groundwater aquifers has become a common practice in different areas of Zanzibar Island. Moreover, during rainy seasons, rainwater is also a potential source of fresh water for domestic and other social purposes and activities.

The issue of water quality is very poignant in many countries, but the vulnerability of water to contaminants due to natural and anthropogenic sources has become a common problem worldwide [1].Water is an inevitable need to man and his environment; it has existed throughout the history of the earth crust even before the existence of man. However, the water qualityis persistently pollutedin many countries of the world [2].

The importance of water quality for the health of human being and welfare is of a great interest and attention in the world. Access to sufficient, clean, and safe water is essential for human survival, and is one among the fundamental human rights. Regarding public health, limited access to safe water obviously undermines other public sectors such as public health, which can lead to communicable diseases. The 
provision of potable drinking water has been highly assembled in national and international documents [3].

The issue of water quality is one of the poignant agenda in many countries. The exploitation and utilization of water from groundwater aquifers has become a common practice in different areas of Zanzibar Island. Nevertheless, the vulnerability of water to contaminants due to natural and anthropogenic sources seems to be a common phenomenon [1]. Moreover, both the qualitative and quantitative aspects of water resources might be vulnerable to deterioration due to environmental degradation. Very recently, about 2.7 million liters of water are anticipitated to be lost at Chunga water supplies located at west region of Zanzibar owing poor utilization of the environment.

Fresh water supply is an important concern worldwide, about $90 \%$ of fresh water in the world originated from groundwater aquifers [4]. An aquifer is an underground component of saturated earth materials that can provide usable quantities of ground water to a well [5].

In Zanzibar, rapid rate of urbanization has increased demand of water, which necessitated the usage of groundwater to supplement the existing water supply systems, in most areas of the Island. Accordingly, the trend of developing privately owned water wells has increased to an amount that has outnumbered the public and community water source [1].

Water resources evaluation typifies a major concern of the present world due to the importance of water for human being and society in general [6]. Good water quality management is fundamental for the production of clean water for the human consumption and safety. Qualitative as well as quantitative determination of the contaminants, along with the predictions of their possible source(s) are vital in an attempt of tackling contamination problems in groundwater and surface water [1]. Therefore, an evaluation of drinking water quality is a crucial concern for implementing sustainable water-use strategies, plan, and policy.

Moreover, information about water quality analysis is always used as a basis to discuss utilizing groundwater in order to avoid associated water illnesses and health problems. [7] Groundwater quality depends, to some extents, on its chemical composition. Monitory of the levels of cations and anions play important and indicative role in assessing degree of groundwater contamination [8]. Nevertheless, an access to good water quality supply and sanitation services has become a hot issue in most of developing countries, and still these services do not reach a significant proportion of the world's population. It has become a more challenging agenda due to factors such as rapid rate of urbanization and environmental pollution.

Harmful impurities from various sources such as, agricultural and domestic effluents, municipal sewerage are among the key factors, which deteriorate the quality portable water [9]. Trace metals are among a wide range of contaminants, which receive health concernsdue to their potential toxicities even at very low concentrations. Trace metals gain entrance into human systems via contaminated drinking water, air, and food. In the body, the metals can compete with, and displace essential minerals such as zinc, copper, magnesium, and calcium; and interfere with body biological organs, systems and functions [10] Over a certain period, metals have tendency to bio-accumulate in tissues of living organisms [11]. However, some trace metals (such as zinc, copper, iron, and manganese) are the micronutrients; the body in small amounts for metabolic activities requires them. At higher concentrations, these same elements, can cause adverse health effects or illness [12].

Toxic metals such as cadmium $(\mathrm{Cd})$, lead $(\mathrm{Pb})$, arsenic (As), chromium $(\mathrm{Cr})$, and thallium $(\mathrm{Tl})$ do not have beneficial effects in humans. Long-term exposures to these metals may cause severe disruptions in the normal dysfunctioning of the organs and systems where the metals are accumulated. $\mathrm{Pb}$, for example, is linked with a broad range of negative pregnancy outcomes, including cardiovascular diseases, early membrane rupture and spontaneous abortion, and erectile dysfunction [13]. Cadmium is very toxic and is linked to several cases of poisoning through food. Small quantities of cadmium cause adverse changes in the arteries of human kidney causing kidney damage. Moreover, cadmium replaces zinc biochemically and causes high blood pressures [14].

Metals such as $\mathrm{Cd}, \mathrm{Cr}, \mathrm{V}, \mathrm{As}, \mathrm{Mn}, \mathrm{Ti}, \mathrm{Co}, \mathrm{Cu}, \mathrm{Fe}, \mathrm{Pb}, \mathrm{Ni}$, $\mathrm{Zn}$, and their compounds have been suggested to be initiators or promoters of carcinogenic activity in animals. Furthermore, $\mathrm{Be}, \mathrm{Sb}, \mathrm{Al}, \mathrm{Hg}, \mathrm{Ni}, \mathrm{Cd}$ and $\mathrm{Co}$ can cause undesirable reproductive/fertility problems [15].

Zinc toxicity can leads to diarrhea [16], manganese may slow down the intellectual development of the child [17]. Iron has been associated with repeated blood transfusions, genetic and metabolic diseases [18], and copper toxicity is related to several health concerns, including kidney disease, stomach cramps, nausea, vomiting, diarrhea, cancer, and liver damage [19].

The presence of chemical species in fresh water sources, such as groundwater aquifers and springs can be of natural or anthropogenic origins. The constituents present in water may pose many health risks to human, and other life when exceed the maximum contamination level. Because of the absence of drinking water treatment plants in Zanzibar, it is mandatory to assess, and to keep regular drinking water monitoring programs. Thus the objective of this study is to examine and highlighting the levels of twelve metals in groundwater and spring sources in urban west region of Zanzibar. The paper also reveals the correlation coefficients between the analyzed parameters, the estimate of the degree of metal contamination $\left(C_{d}\right)$. Other hazard and pollution indices were also studied.

\section{Materials and Methods}

December 2012, samples of water were collected from twenty-eight ground water sources and two springs located at Urban-west region and its territoriesof Zanzibar Island. Geographic coordinates of all sampling points were recorded using the Global Positioning System (GPS). Sampling sites 
are shown in Figure 1). Water samples from 30 locations were collected in sterile bottles $(1000 \mathrm{~mL})$ preserved, and analyzed by using standard methods for the examination of water and wastewater [20]. These water sources were closed hand dug well (CHDW), open hand dug well (OHDW), public bore well (PBW), spring water (SW), and bore well owned by private individual or community owned well (BWP). Prior to sampling process, all the bottles were cleaned and rinsed thoroughly with water to be analyzed. All reagents used were of analytical grade. The water samples were stored at $4^{\circ} \mathrm{C}$ prior to laboratory chemical analysis. Metal analyzed are $\mathrm{Cd}, \mathrm{Co}, \mathrm{Cr}$ (III), Cu, Fe, Li, Mn, Mo, Sb, $\mathrm{Se}, \mathrm{Ti}$, and $\mathrm{Zn}$. The concentrations of these metals were determined using ICP-OES (Thermo Scientific iCAP 6000). The ICP-OES is robust and can undergo multi elemental analysis $[1,3]$.

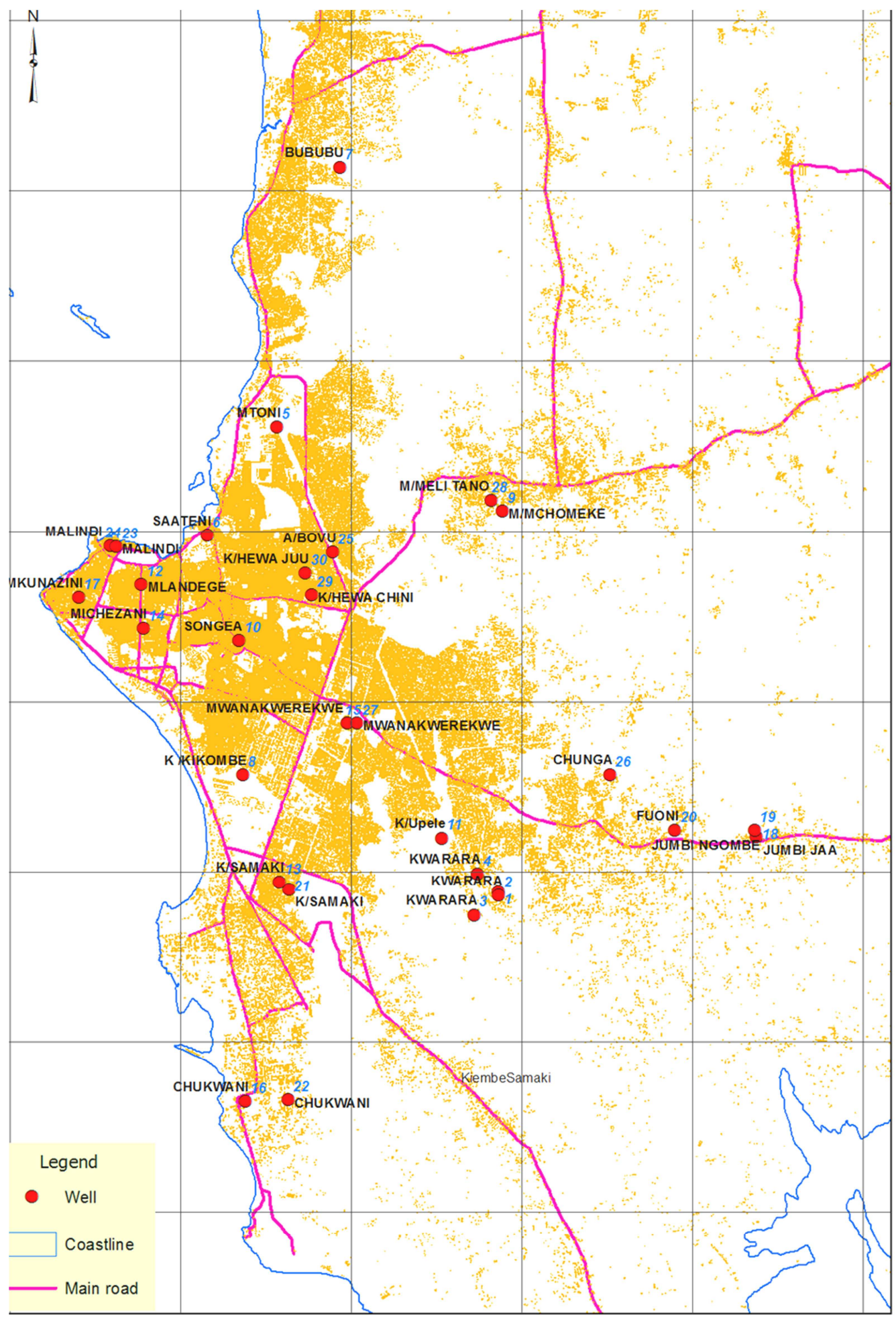

Figure 1. Map of sampling sites in Zanzibar Urban-West Region and territories. 


\subsection{Data Analysis}

IBM Statistical Package for the Social Sciences (SPSS) version 16 was used to give descriptive statistics from the data analysis. Concentrations of the analyzed trace metal within and between the water sources were not significant different (Table-1).

Table 1. Summary of the descriptive statistics of the analyzed parameters.

\begin{tabular}{|c|c|c|c|c|c|c|c|c|}
\hline Parameters & df & $\mathbf{F}$ & Sig. & Mean & Std. Deviation & Minimum & Maximum & $\mathbf{N}$ \\
\hline $\mathrm{Cd}$ & 4 & 0.946 & 0.454 & 0.0006 & 0.00031 & 0.0001 & 0.0014 & 30 \\
\hline Co & 4 & 1.912 & 0.140 & 0.0002 & 0.00026 & BDL & 0.0009 & 30 \\
\hline $\mathrm{Cr}(\mathrm{III})$ & 4 & 1.262 & 0.311 & 0.0124 & 0.01809 & BDL & 0.0465 & 30 \\
\hline $\mathrm{Cu}$ & 4 & 0.419 & 0.794 & 0.0069 & 0.02028 & BDL & 0.111 & 30 \\
\hline $\mathrm{Fe}$ & 4 & 0.543 & 0.706 & 0.0031 & 0.00794 & BDL & 0.035 & 30 \\
\hline $\mathrm{Li}$ & 4 & 1.196 & 0.337 & 0.0075 & 0.01758 & 0.0002 & 0.0985 & 30 \\
\hline $\mathrm{Mn}$ & 4 & 0.329 & 0.856 & 0.0009 & 0.00233 & BDL & 0.0089 & 30 \\
\hline Mo & 4 & 0.582 & 0.678 & 0.0002 & 0.00055 & BDL & 0.0028 & 30 \\
\hline $\mathrm{Sb}$ & 4 & 0.710 & 0.593 & 0.0021 & 0.00173 & BDL & 0.0074 & 30 \\
\hline $\mathrm{Se}$ & 4 & 0.867 & 0.497 & 0.0027 & 0.00413 & BDL & 0.0135 & 30 \\
\hline $\mathrm{Ti}$ & 4 & 1.531 & 0.224 & 0.0038 & 0.00183 & 0.00031 & 0.0071 & 30 \\
\hline $\mathrm{Zn}$ & 4 & 0.413 & 0.798 & 0.0158 & 0.04358 & 0.00013 & 0.2339 & 30 \\
\hline
\end{tabular}

\subsection{The Estimate of the Pollution Indices and Degree of Metal Contamination}

The present study evaluated heavy metal pollution index (HPI) proposed by [21], the degree of contamination $\left(\mathrm{C}_{\mathrm{d}}\right)$ developed by [22]. $\mathrm{C}_{\mathrm{d}}$ is also gives an indication for the extent of metal pollution [23]. Degree of contamination in water resources can fall in to one of three categories, namely, low $\left(\mathrm{C}_{\mathrm{d}}<1\right)$, medium $\left(\mathrm{C}_{\mathrm{d}}=1-3\right)$, and high $\left(\mathrm{C}_{\mathrm{d}}>3\right)$ [23]. Another pollution index is "Heavy metal evaluation index" (HEI), it gives an overall quality of the water with respect to heavy metals [24]. Figure A2 shows the value of the calculated indices. Toxicity response due to $\mathrm{Fe}, \mathrm{Cu}, \mathrm{Cd}$, and $\mathrm{Zn}$ exposures are shown in Table-2.

Table 2. Toxicity response due to $\mathrm{Fe}, \mathrm{Cu}, \mathrm{Cd}$, and $\mathrm{Zn}$ exposures.

\begin{tabular}{llll}
\hline \multicolumn{2}{l}{ Toxicity Response [25] } & \multicolumn{2}{l}{ Exposure Parameters } \\
\hline Parameter & Oral RfD (mg/Kg/day) & IR & $\mathbf{2 . 2}$ L/day \\
\hline $\mathrm{Fe}$ & 0.7 & EF & 365 Days/year \\
$\mathrm{Cu}$ & 0.04 & ED & 70 years \\
$\mathrm{Cd}$ & 0.0005 & BW & $70 \mathrm{Kg}$ \\
$\mathrm{Zn}$ & 0.3 & AT & 25550 days \\
\hline
\end{tabular}

The pollution indices and other hazard indices were calculate using the follow shown below:

\subsubsection{Degree of Contamination $\left(C_{d}\right)$}

$$
C_{d}=\sum_{i=1}^{n} C_{f i}
$$

$\mathrm{C}_{\mathrm{fi}}$ is a sub-index showing contamination factor, and is calculated according to Eq. (2)

$$
C_{f i}=\frac{C M_{i}}{C S_{i}}-1
$$

$\mathrm{C}_{\mathrm{fi}}, \mathrm{CM}_{\mathrm{i}}$, and $\mathrm{CS}_{\mathrm{i}}$, are the contamination factor, analytical value, and upper permissible concentration for $i^{\text {th }}$ component respectively, while $\mathrm{n}$ denotes the 'normative value'.

\subsubsection{Heavy Metal Pollution Index (HPI)}

$$
H P I=\sum_{i=1}^{n} W i Q i / \sum_{i=1}^{n} W i
$$

Where: Wi and Qi are unit weight and the sub-index of the $i^{\text {th }}$ parameter, respectively, and $n$ is the number of parameters considered. The sub-index (Qi) is calculated according to Eq. (4).

$$
Q i=\sum_{i=1}^{n} \frac{|M i-I i|}{S i-I i} \times 100
$$

\subsubsection{Heavy Metal Evaluation Index (HEI)}

$$
H E I=\sum_{i=1}^{n} \frac{H_{c}}{H_{m a c}}
$$

Where:

$\mathrm{H}_{\mathrm{c}}=$ Analyzed concentration of the respective parameter.

$\mathrm{H}_{\text {mac }}=$ Maximum admissible concentration of the respective parameter.

\subsubsection{Hazard Quotient (HQ)}

$$
H Q=\frac{A D D}{R f D}
$$


Where ADD is the average daily dose, which is calculated using equation 7 .

$$
A D D_{i}=\frac{C i \times I R \times E F \times E D}{B W \times A T}
$$

Where:

$\mathrm{C}_{\mathrm{i}}=$ Concentration of the monitored parameter

$\mathrm{IR}=$ Ingestion rate

$\mathrm{EF}=$ Exposure frequency

$\mathrm{ED}=$ Exposure Duration

$\mathrm{BW}=$ Body weight

$\mathrm{AT}=$ Average time

\subsubsection{Hazard Index (HI)}

$$
H I=\sum H Q_{i}
$$

\subsubsection{Chronic Daily Intake CDI}

Chronic daily intake is calculated using modified equation 9 [26].

$$
C D I=C i \times \frac{D I}{B W}
$$

\section{Results and Discussion}

\subsection{Correlation of Trace Metals in the Water Samples}

As shown in Table 3, the correlation among the analyzed trace metals in water samples are expressed by Pearson coefficient. Copper, selenium, and manganese had strong correlation with zinc $(\mathrm{r}=0.933)$, chromium III $(\mathrm{r}=0.827)$, and manganese $(r=0.63)$, respectively. Negative correlations were also observed, for instance, iron had negative correlations with cadmium, cobalt, and chromium (III). The correlation between same parameters is not necessarily uniform, and it can remarkably differ from one study area to another. In the context of analytical chemistry, the correlation matrix is both fundamental and pervasive concept, and it does not necessarily mean the presence of causality among the analyzed parameters.

Table 3. The Correlation between Trace metals in the water samples.

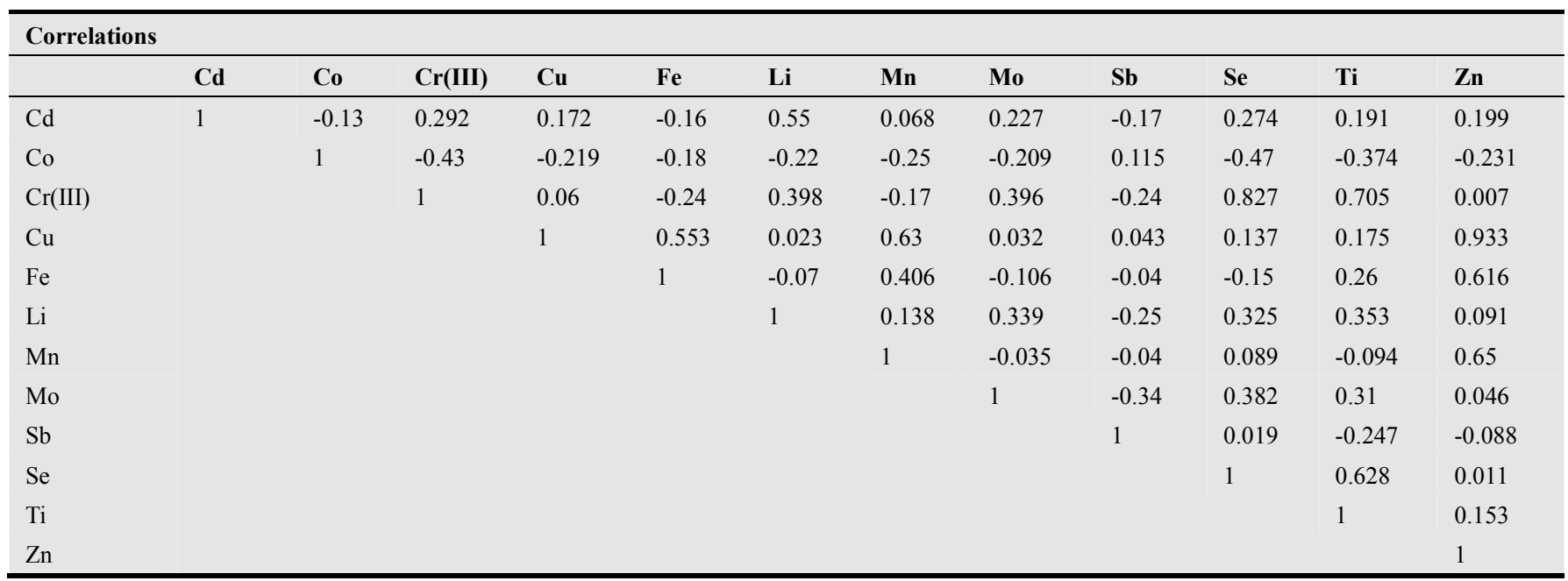

\subsection{Cadmium, Cobalt, Cr(III) and Copper in Different Water Sources}

The concentrations of cadmium, cobalt, chromium III, and copper were in the ranges of $0.0001-0.0014$, BDL -0.0009 , BDL $-0.0465, \mathrm{BDL}-0.111 \mathrm{mgL}^{-1}$ respectively (Table- 1 and Figure A1). In decreasing order of the concentrations, the general trend of the analyzed trace metals in different water sources were: chromium (III) $>$ copper $>$ cadmium $>$ cobalt (Figure 2). Cadmium was detected in all 30 sampling areas followed by copper, chromium (III), and cobalt, which were detected in 18,14 , and 14 of the sampling sites respectively (Figure A1). While the natural sources of cadmium in the analyzed water samples cannot be directly excluded, the detected concentration of cadmium are associated with activities in which cadmium is used as important component in different application, such as pigments, plastics, and battery.

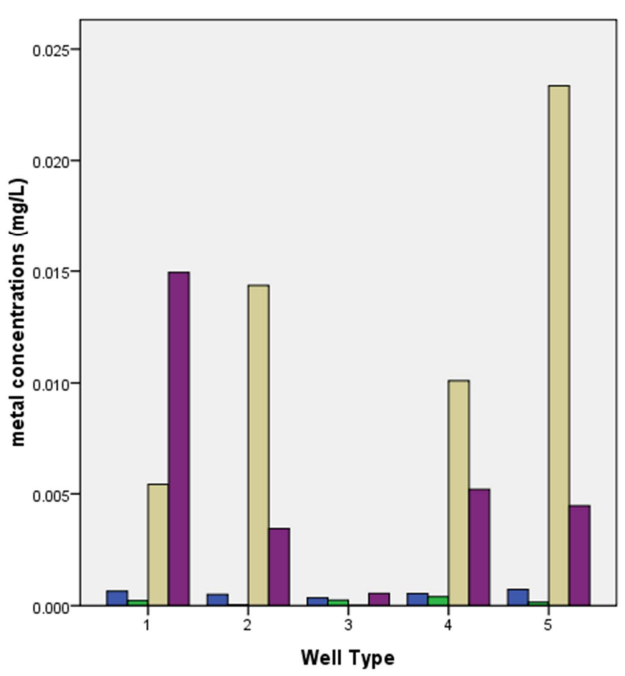

Figure 2. Cadmium, Cobalt, Cr(III) and Copper in Different Water Sources. 


\subsection{Iron, Lithium, Manganese and Molybnenumin Different Water Sources}

The concentrations of iron, lithium, manganese and molybdenum were in the ranges of $\mathrm{BDL}-0.035 ; 0.0002-$ $0.0985 ; \mathrm{BDL}-0.0089$, and $\mathrm{BDL}-0.0028 \mathrm{mgL}^{-1}$ respectively (Table-1 and Figure A1).The general trend of the analyzed trace metals in different water sources in decreasing order of their concentrations were: lithium $>$ iron $>$ manganese $>$ molybdenum (Figure 3). Lithium was detected in all 30 sampling areas followed by iron, manganese, and molybdenum, which were detected in 24,14 , and 3 of the sampling sites respectively (Figure A1). As in the case of cadmium, the detected concentration of lithium are associated with anthropogenic activities in which lithiumcontaining materials such as batteries are improperly disposed in the environment. Because the soil is the major sink of all the metals in Earth crust, therefore the occurrence and the detected concentrations of the trace metals in water sources is not an anomalous event.

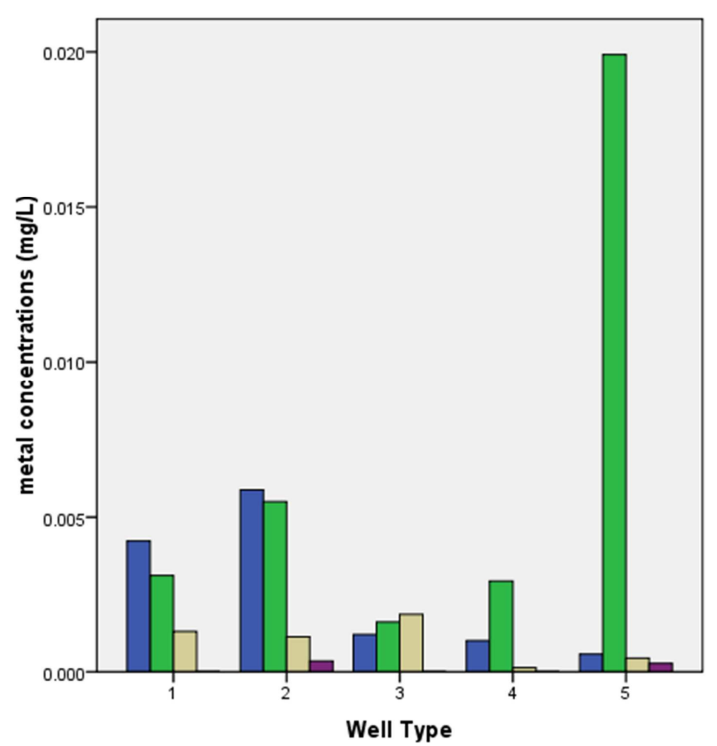

Figure 3. Iron, Lithium, Manganese and Molybnenum in Different Water Sources.

\subsection{Antimony, Selenium, Titanium and Zinc in Different Water Sources}

The concentrations of antimony, selenium, titanium and zinc were in the ranges of $\mathrm{BDL}-0.0074$; $\mathrm{BDL}-0.0135$;
$0.00031-0.0071$, and $0.00031-0.0071 \mathrm{mgL}^{-1}$ respectively (Table-1 and Figure A1).The general trend of the analyzed trace metals in different water sources in decreasing order of their concentrations were: zinc $>$ titanium $>$ selenium $>$ antimony (Figure 4). Zinc and titanium were detected in all 30 sampling areas followed by antimony, and selenium, which were detected in 24 , and 16 of the sampling sites respectively (Figure A1). These trace metals are naturally present in the earth crust; however, anthropogenic pressure may enhance their levels in a given environment. The leachates of domestic effluents with residues of titanium containing shampoos and soaps may penetrate the soil and conduit into groundwater resources.

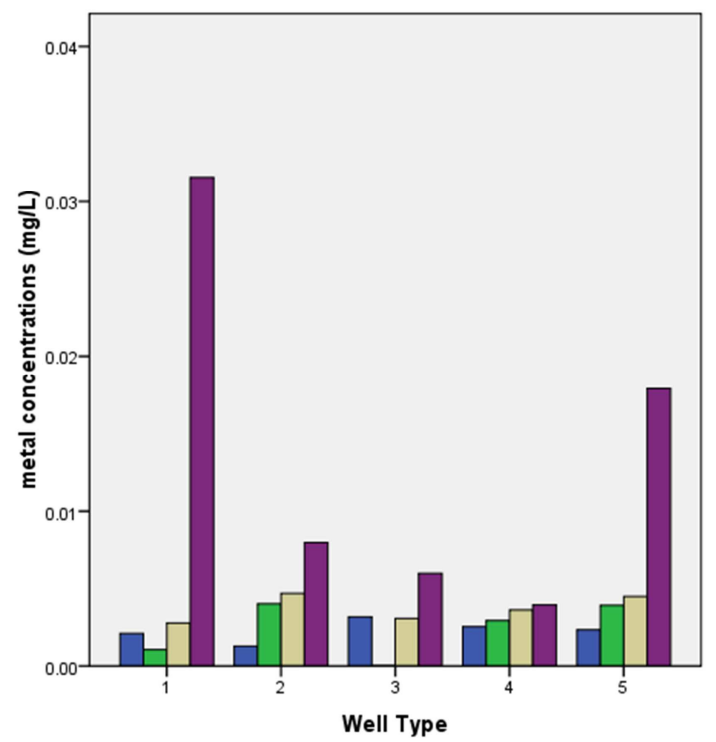

Figure 4. Antimony, Selenium, Titanium, and Zinc in Different Water Sources.

\subsection{Occurrence of Metals in Water Sources}

Table-4 gives a summary of the occurrence of metals in five different sources (CHDW, OHDW, SW, PBW, and BWP) from which water samples were collected.Cadmium, zinc, and lithium prevailed in all water sources. Titanium also existed in more than $80 \%$ of the water sources. Molybnenum abundance was the least inthe prevailing metals.

Table 4. Percentage occurrence of the analyzed parameters in water sources.

\begin{tabular}{|c|c|c|c|c|c|c|c|c|c|c|c|c|}
\hline $\begin{array}{l}\text { Water } \\
\text { source }\end{array}$ & $(\%) \mathrm{Cd}$ & $\% \mathrm{Co}$ & $\%$ Cr III & $\% \mathrm{Cu}$ & $\% \mathrm{Fe}$ & $\% \mathbf{L i}$ & \% Mn & \% Mo & $\% \mathrm{Sb}$ & $\% \mathrm{Se}$ & $\% \mathrm{Ti}$ & $\% \mathrm{Zn}$ \\
\hline CHDW & 100 & 12.5 & 25 & 50 & 87.5 & 100 & 50 & 0 & 87.5 & 50 & 100 & 100 \\
\hline OHDW & 100 & 25 & 75 & 75 & 87.5 & 100 & 25 & 12.5 & 62.5 & 75 & 100 & 100 \\
\hline SW & 100 & 50 & 0 & 50 & 100 & 100 & 100 & 0 & 100 & 0 & 100 & 100 \\
\hline PBW & 100 & 80 & 60 & 40 & 80 & 100 & 60 & 0 & 100 & 40 & 100 & 100 \\
\hline BWP & 100 & 37.5 & 50 & 75 & 50 & 100 & 37.5 & 25 & 25 & 50 & 87.5 & 100 \\
\hline
\end{tabular}




\subsection{Human Health Risk Assessment Due to Toxic Metal}

Heavy metals are toxic elements, and they are in the list of the noxious pollutants in the context of environmental and health sciences. Ingestion of considerable amount of heavy metals via different exposure pathways may result into several detrimental ill effects. Using the four heavy metals $(\mathrm{Cd}, \mathrm{Zn}, \mathrm{Cu}$, and $\mathrm{Fe})$, the degree of contamination $\left(\mathrm{C}_{\mathrm{d}}\right)$ in all water sources were less than 1 , thus they all fall in to the category of low degree of contamination. Similar trend was found in the study conducted in Tehran water sources [27].

The general trend of the average daily dose (ADD) of $\mathrm{Zn}$, $\mathrm{Cu}, \mathrm{Fe}$, and $\mathrm{Cd}$ in water sources is:

$$
\mathrm{Zn}>\mathrm{Cu}>\mathrm{Fe}>\mathrm{Cd} \text {. }
$$

With regard to severity of the toxicity, cadmium is highly toxic, so this trend likely does not show alarming situation in the context of cadmium risk in the water sources. As the severity of toxicity is governed by several factors such as dose, nutrition, age and even life style. Therefore, this trend might not guarantee the absence of human health risk (Figure 5).

For the case of $\mathrm{C}_{\mathrm{d}}$, there is a remarkable spatial variation in different water sources. While for HPI the spatial variations is less remarkable. HPI for all water samples were well below the critical value (Figure 6).

All water samples $(100 \%)$ to some extent showed some levels of HEI. Moreover, all water samples showed some ADD levels with respect to $\mathrm{Cd}, \mathrm{Zn}$, and copper metal, while iron metal was over $60 \%$. Nevertheless, the spatial variations of $\mathrm{HI}$ are more apparent as compared to HEI (Figure $7 \&$ Figure A2).

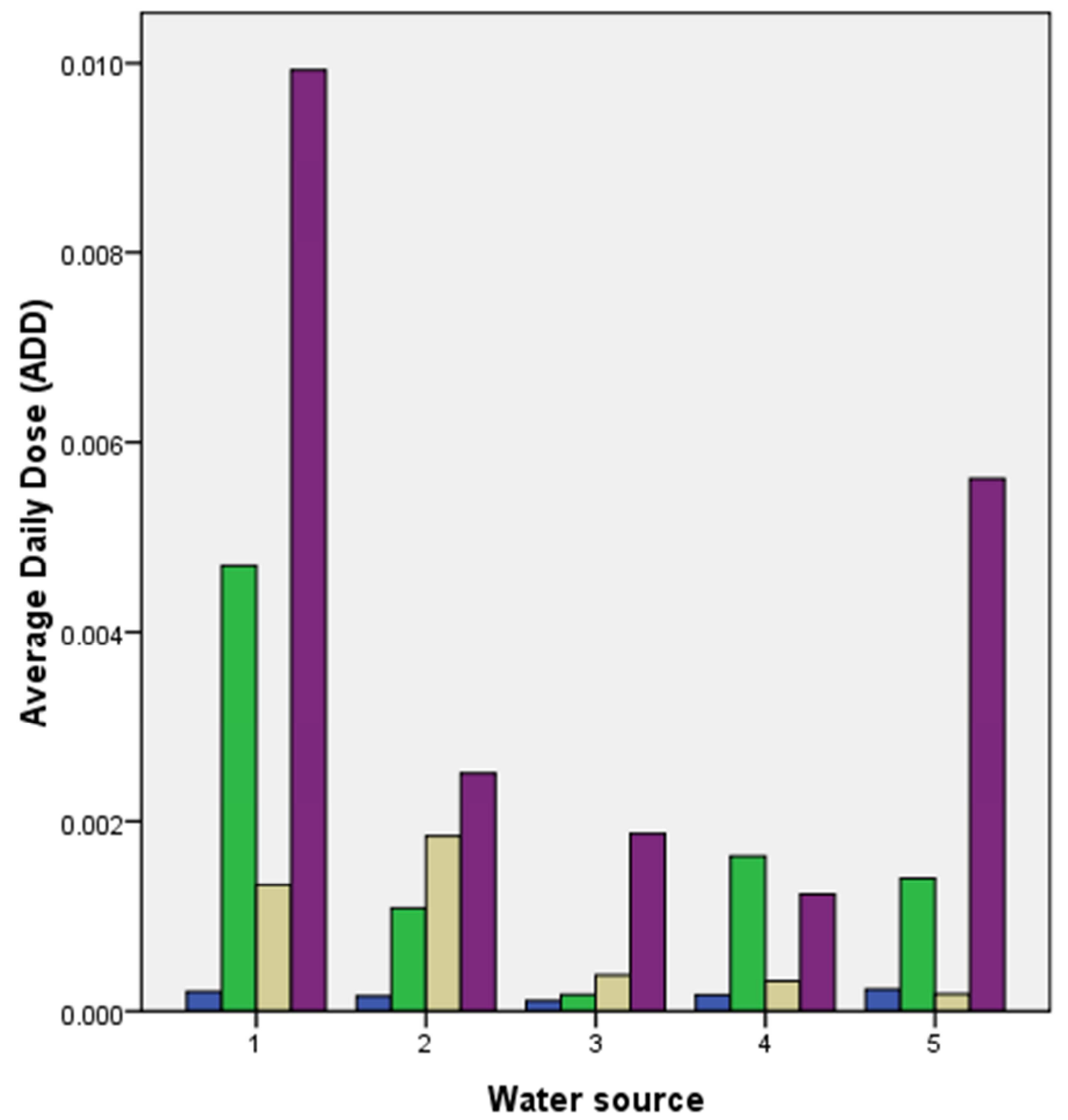

Figure 5. $A D D$ of $C d$. $\mathrm{Cu}, \mathrm{Fe}$ and $\mathrm{Zn}$. 


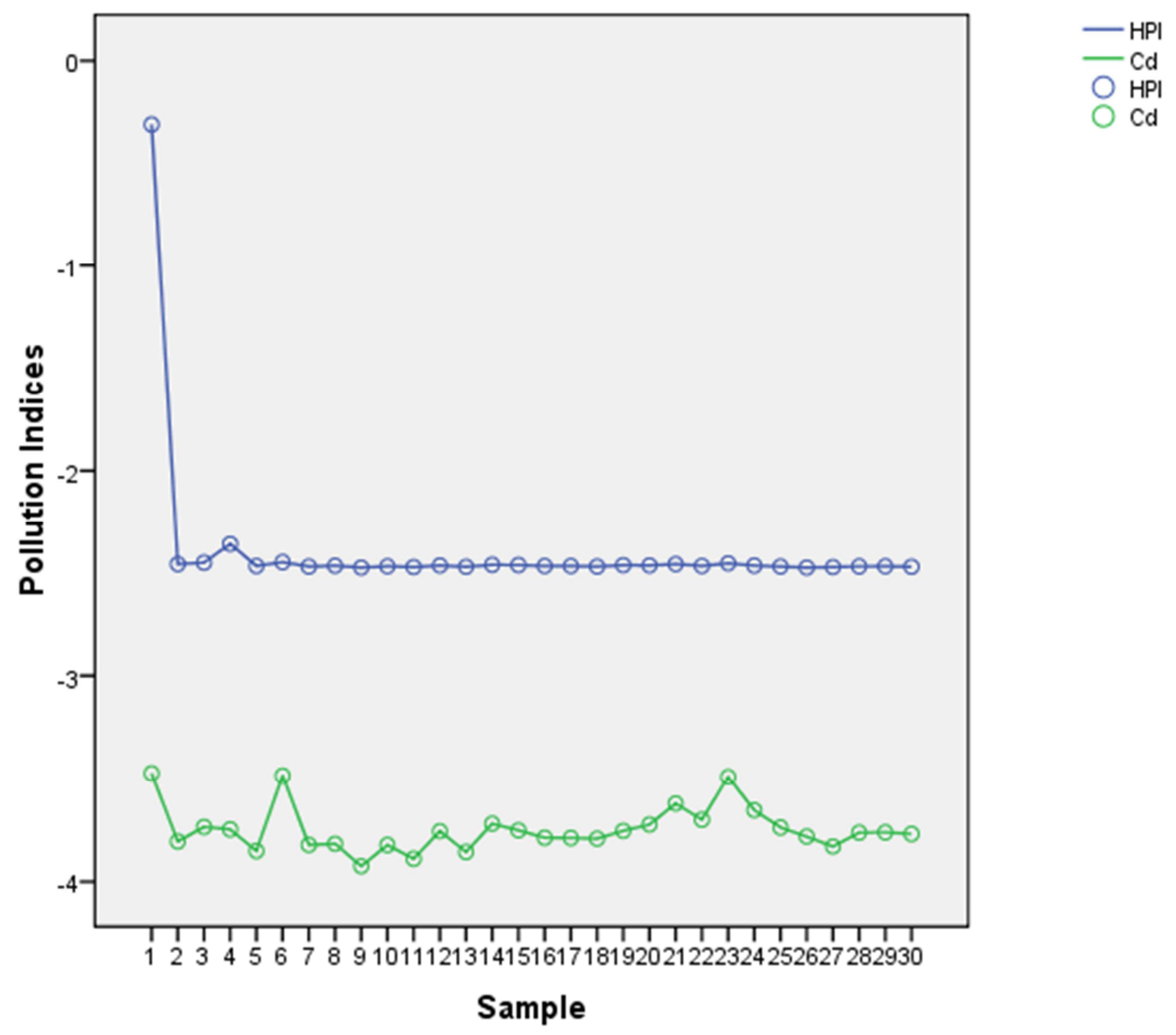

Figure 6. HPI and $C_{d}$ in water samples.

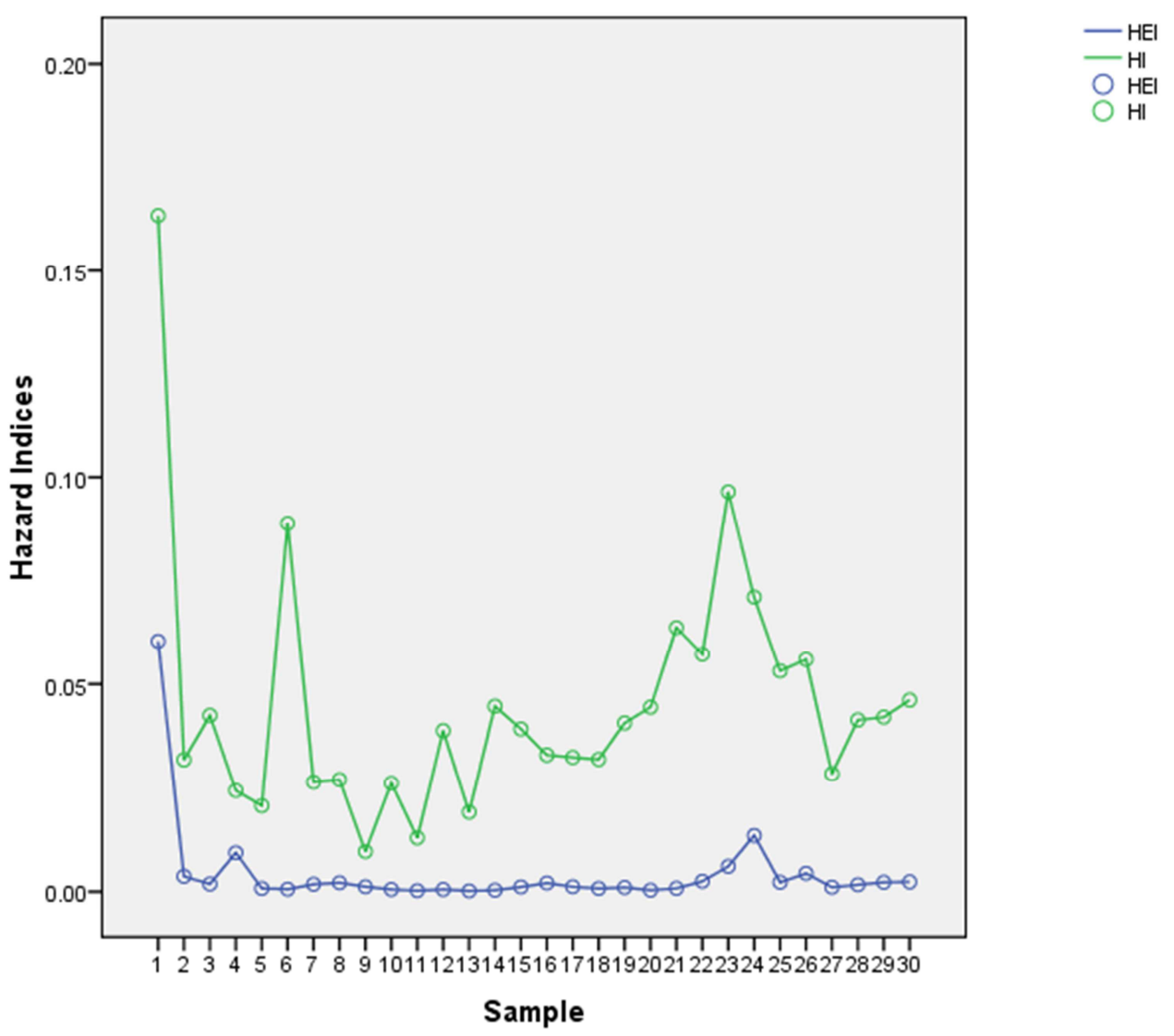

Figure 7. Hazard index in water samples. 


\section{Conclusion}

From the twelve analyzed metals, cadmium, zinc, and lithium existed at varying concentrations in all water sources. Other metals were also detected though at relatively low abundances. Generally, from risk assessment on trace metals using risk indices $\left(\mathrm{C}_{\mathrm{d}}, \mathrm{HPI}, \mathrm{HI}\right.$ and $\left.\mathrm{HEI}\right)$, the analyzed water sources are not at the alarming health risk, however, the increasing level of environmental pollution, water sources might be potential sink of contaminants, this is significant reason that make the treatment of drinking water and monitoring implementation inevitable.

\section{Appendix}

\begin{tabular}{|c|c|c|c|c|c|c|c|c|c|c|c|c|c|}
\hline $\begin{array}{c}\text { Sampling } \\
\text { site }\end{array}$ & $\mathrm{Cd}$ & Co & $\mathrm{Cr}$ III & $\mathrm{Cu}$ & $\mathrm{Fe}$ & $\mathrm{Li}$ & $\mathrm{Mn}$ & Mo & $\mathrm{Sb}$ & $\mathrm{Se}$ & $\mathrm{Ti}$ & $\mathrm{Zn}$ & $\begin{array}{l}\text { Well } \\
\text { Type }\end{array}$ \\
\hline 1 & 0.8 & nd & 0.2 & 111 & 28.5 & 3.8 & 8.9 & nd & 2.2 & 1 & 4.2 & 234 & 1 \\
\hline 2 & 0.4 & nd & 1.4 & 4.1 & 4.5 & 4.7 & 8.9 & nd & 1.6 & 7.5 & 3.2 & 13.9 & 2 \\
\hline 3 & 0.6 & nd & 3.5 & 2.6 & 5.4 & 7.5 & nd & nd & 3.3 & 0.2 & 4 & 2.8 & 2 \\
\hline 4 & 0.1 & nd & 2.3 & nd & 35 & 4.2 & nd & nd & 1.4 & 1 & 7.1 & 23.1 & 2 \\
\hline 5 & 0.3 & 0.5 & nd & 1.1 & 1.9 & 3 & 0.1 & nd & 3.3 & nd & 5.8 & 1.6 & 3 \\
\hline 6 & 1.4 & 0.5 & 0.5 & nd & 1.7 & 2.2 & nd & nd & 2.1 & 1.1 & 4.5 & 0.7 & 4 \\
\hline 7 & 0.4 & nd & nd & nd & 0.5 & 0.2 & 3.6 & nd & 3 & nd & 0.3 & 10.3 & 3 \\
\hline 8 & 0.4 . & 0.1 & nd & nd & 1.6 & 0.5 & 0.39 & nd & 0.7 & nd & 3 & 11.3 & 4 \\
\hline 9 & 0.1 & 0.9 & 11.7 & 3.4 & 0.9 & 0.5 & nd & nd & 2.2 & nd & 3.1 & 3 & 4 \\
\hline 10 & 0.4 & 0.6 & nd & 0.6 & 0.9 & 1.3 & 0.2 & nd & 1.2 & nd & 2.6 & 1.5 & 1 \\
\hline 11 & 0.2 & 0.5 & nd & nd & 0.8 & 0.9 & 0.2 & nd & 3 & nd & 1.7 & 0.5 & 4 \\
\hline 12 & 0.6 & 0.4 & nd & 0.7 & 1 & 0.8 & 0.1 & nd & 3.9 & nd & 2.4 & 1 & 5 \\
\hline 13 & 0.3 & nd & nd & nd & 0.7 & 0.8 & 0.9 & nd & 2.7 & 0.1 & 2.5 & 0.19 & 1 \\
\hline 14 & 0.7 & 0.6 & nd & nd & 1.5 & 0.6 & 0.4 & nd & 3.6 & nd & 0.8 & 0.13 & 1 \\
\hline 15 & 0.6 & 0.6 & nd & 0.4 & 1.6 & 7.6 & 0.1 & nd & 1.2 & nd & 3.7 & 4.5 & 5 \\
\hline 16 & 0.5 & 0.1 & nd & nd & 0.7 & 4.4 & nd & nd & 3.4 & nd & 1.9 & 11.7 & 5 \\
\hline 17 & 0.5 & nd & nd & nd & 0.7 & 3.1 & nd & nd & 3.8 & nd & 2.3 & 6.1 & 1 \\
\hline 18 & 0.5 & 0.1 & nd & nd & 0.1 & 7.7 & nd & nd & 2.8 & nd & 3.8 & 4.3 & 2 \\
\hline 19 & 0.6 & 0.1 & nd & 2.6 & 1.7 & 3.5 & nd & nd & 1.1 & nd & 2.7 & 1.3 & 2 \\
\hline 20 & 0.7 & 0.3 & nd & 0.1 & 0.6 & 0.5 & nd & nd & 2.6 & 0.4 & 1.7 & 0.9 & 1 \\
\hline 21 & 1 & 0.3 & nd & nd & 1 & 4.1 & nd & nd & 0.6 & nd & 2 & 3 & 1 \\
\hline 22 & 0.8 & nd & 43.2 & 7.8 & nd & 10.6 & nd & nd & nd & 6.9 & 6 & 7 & 1 \\
\hline 23 & 1.4 & nd & 38 & 6.5 & 0.7 & 98.5 & 2.9 & 1 & nd & 7.1 & 6 & 29.2 & 5 \\
\hline 24 & 0.9 & nd & 46.5 & 8.4 & nd & 16.5 & nd & 0.9 & 0.4 & 6.9 & 6 & 74.6 & 5 \\
\hline 25 & 0.7 & nd & 42.6 & 11.4 & nd & 7.6 & nd & nd & 7.4 & 12.1 & 6 & 1.9 & 5 \\
\hline 26 & 0.6 & nd & 38.3 & 22.6 & nd & 10.5 & 0.1 & nd & 4.6 & 13.5 & 5.7 & 4.1 & 4 \\
\hline 27 & 0.4 & nd & 36.4 & 3.9 & nd & 4 & nd & nd & nd & 1.2 & 5.3 & 2.3 & 5 \\
\hline 28 & 0.6 & nd & 36.4 & 3.9 & nd & 3.6 & nd & nd & $\mathrm{Nd}$ & 6.4 & 5.1 & 5.8 & 2 \\
\hline 29 & 0.6 & nd & 37.8 & 4.2 & 0.2 & 6.4 & 0.1 & nd & $\mathrm{Nd}$ & 8 & 5.8 & 9 & 2 \\
\hline 30 & 0.6 & nd & 33.5 & 10.2 & 0.1 & 6.4 & nd & 2.8 & nd & 8.9 & 5.6 & 3.7 & 2 \\
\hline
\end{tabular}

Figure A1. Analyzed parameters all in $\mu g L^{-1} ;$ nd: not detected; $1=C H D W ; 2=O H D W ; 3=S W ; 4=P B W ; 5=B W P$. 


\begin{tabular}{ccc} 
Sample & $\mathbf{C}_{\mathbf{d}}$ & HPI \\
1 & -3.473 & -0.3080 \\
2 & -3.805 & -2.4553 \\
3 & -3.735 & -2.4482 \\
4 & -3.747 & -2.3572 \\
5 & -3.851 & -2.4646 \\
6 & -3.485 & -2.4459 \\
7 & -3.822 & -2.4674 \\
8 & -3.816 & -2.4637 \\
9 & -3.925 & -2.4722 \\
10 & -3.822 & -2.4661 \\
11 & -3.889 & -2.4697 \\
12 & -3.756 & -2.4623 \\
13 & -3.856 & -2.4683 \\
14 & -3.719 & -2.4587 \\
15 & -3.752 & -2.4603 \\
16 & -3.787 & -2.4650 \\
17 & -3.789 & -2.4649 \\
18 & -3.792 & -2.4669 \\
19 & -3.754 & -2.4606 \\
20 & -3.724 & -2.4618 \\
21 & -3.621 & -2.4552 \\
22 & -3.700 & -2.4645 \\
23 & -3.490 & -2.4516 \\
24 & -3.653 & -2.4627 \\
25 & -3.738 & -2.4672 \\
26 & -3.782 & -2.4724 \\
27 & -3.830 & -2.4701 \\
28 & -3.763 & -2.4667 \\
29 & -3.761 & -2.4662 \\
30 & -3.769 & -2.4683 \\
& & \\
\hline & & 0 \\
15
\end{tabular}

$\begin{array}{ccccc}\text { HEI } & \text { ADD: } \text { Cd } & \text { ADD: } \mathrm{Cu} & \text { ADD: Fe } & \text { ADD: } Z \text { n } \\ 0.06033 & 2.51 \mathrm{E}-05 & 0.003489 & 0.00090 & 0.007351 \\ 0.00369 & 1.26 \mathrm{E}-05 & 0.000129 & 0.00141 & 0.000437 \\ 0.00184 & 1.89 \mathrm{E}-05 & 8.17 \mathrm{E}-05 & 0.00170 & 0.000088 \\ 0.00938 & 3.14 \mathrm{E}-06 & 0 & 0.01100 & 0.000726 \\ 0.00079 & 9.43 \mathrm{E}-06 & 3.46 \mathrm{E}-05 & 0.00060 & 5.03 \mathrm{E}-05 \\ 0.00061 & 0.000044 & 0 & 0.00053 & 0.000022 \\ 0.00181 & 1.26 \mathrm{E}-05 & 0 & 0.00016 & 0.000324 \\ 0.00214 & 1.26 \mathrm{E}-05 & 0 & 0.00050 & 0.000355 \\ 0.00119 & 3.14 \mathrm{E}-06 & 0.000107 & 0.00028 & 9.43 \mathrm{E}-05 \\ 0.00055 & 1.26 \mathrm{E}-05 & 1.89 \mathrm{E}-05 & 0.00028 & 4.71 \mathrm{E}-05 \\ 0.00024 & 6.29 \mathrm{E}-06 & 0 & 0.00025 & 1.57 \mathrm{E}-05 \\ 0.00053 & 1.89 \mathrm{E}-05 & 0.000022 & 0.00031 & 3.14 \mathrm{E}-05 \\ 0.00019 & 9.43 \mathrm{E}-06 & 0 & 0.00022 & 5.97 \mathrm{E}-06 \\ 0.00038 & 0.000022 & 0 & 0.00047 & 4.09 \mathrm{E}-06 \\ 0.00114 & 1.89 \mathrm{E}-05 & 1.26 \mathrm{E}-05 & 0.00050 & 0.000141 \\ 0.00208 & 1.57 \mathrm{E}-05 & 0 & 0.00022 & 0.000368 \\ 0.00118 & 1.57 \mathrm{E}-05 & 0 & 0.00022 & 0.000192 \\ 0.00079 & 1.57 \mathrm{E}-05 & 0 & 0.00003 & 0.000135 \\ 0.00100 & 1.89 \mathrm{E}-05 & 8.17 \mathrm{E}-05 & 0.00053 & 4.09 \mathrm{E}-05 \\ 0.00037 & 0.000022 & 3.14 \mathrm{E}-06 & 0.00019 & 2.83 \mathrm{E}-05 \\ 0.00081 & 3.14 \mathrm{E}-05 & 0 & 0.00031 & 9.43 \mathrm{E}-05 \\ 0.00251 & 2.51 \mathrm{E}-05 & 0.000245 & 0.00000 & 0.00022 \\ 0.00609 & 0.000044 & 0.000204 & 0.00022 & 0.000918 \\ 0.01353 & 2.83 \mathrm{E}-05 & 0.000264 & 0.00000 & 0.002345 \\ 0.00226 & 0.000022 & 0.000358 & 0.00000 & 5.97 \mathrm{E}-05 \\ 0.00440 & 1.89 \mathrm{E}-05 & 0.00071 & 0.00000 & 0.000129 \\ 0.00106 & 1.26 \mathrm{E}-05 & 0.000123 & 0.00000 & 7.23 \mathrm{E}-05 \\ 0.00166 & 1.89 \mathrm{E}-05 & 0.000123 & 0.00000 & 0.000182 \\ 0.00226 & 1.89 \mathrm{E}-05 & 0.000132 & 0.00006 & 0.000283 \\ 0.00235 & 1.89 \mathrm{E}-05 & 0.000321 & 0.00003 & 0.000116\end{array}$

\begin{tabular}{|c|c|}
\hline HI & Water Source \\
\hline 0.1633 & 1 \\
\hline 0.0318 & 2 \\
\hline 0.0425 & 2 \\
\hline 0.0244 & 2 \\
\hline 0.0207 & 3 \\
\hline 0.0888 & 1 \\
\hline 0.0264 & 3 \\
\hline 0.0270 & 4 \\
\hline 0.0097 & 4 \\
\hline 0.0262 & 1 \\
\hline 0.0130 & 4 \\
\hline 0.0388 & 5 \\
\hline 0.0192 & 1 \\
\hline 0.0447 & 1 \\
\hline 0.0392 & 5 \\
\hline 0.0330 & 5 \\
\hline 0.0324 & 1 \\
\hline 0.0319 & 2 \\
\hline 0.0407 & 2 \\
\hline 0.0444 & 1 \\
\hline 0.0636 & 1 \\
\hline 0.0571 & 1 \\
\hline 0.0965 & 5 \\
\hline 0.0710 & 5 \\
\hline 0.0532 & 5 \\
\hline 0.0559 & 4 \\
\hline 0.0284 & 5 \\
\hline 0.0414 & 2 \\
\hline 0.0420 & 2 \\
\hline 0.0462 & 2 \\
\hline
\end{tabular}

Figure A2. Pollution indices in water samples.

\section{Acknowledgement}

We highly acknowledge to His Majesty Government of Brunei Darussalam for funding this project. State University of Zanzibar for supporting the study. We also thank Hjh Faridah, Azzlin, Najib and other UBD chemistry laboratory staffs for their tireless assistance.

\section{References}

[1] Mohamed AAJ, Ibrahim AR, Lee HL, Hanna M, Mohamed M, Fadilah T, Nur AR (2016) Assessment of Groundwater Quality Parameters in Northern Region of Zanzibar Island, J Chem Eng Bioanalyticalchem, 1: 1-8.

[2] Shittu A, Chifu EN, Abdussalam BS, Hafeez YH (2016) Evaluation of Radioactivity Concentration in Drinking Water Collected from Local Wells and Boreholes of Dutse Town, North West, Nigeria Int J Envi Monit Analy, 4: 6-11.

[3] Mohamed AAJ, Ibrahim AR, Lee HL, Khamis SA, Mwevura H, Mbwana KH. (2016) An Index Approach to Metallic Pollution in Groundwater Sources of South Region of Pemba Island, Scie J Analyt Chem, 4: 12-21.

[4] Armon R, Kitty J (1994) The Health Dimension of
Groundwater Contamination. In: Groundwater Contamination and Control, Holler (Ed.), Marcel Dekker, Inc, New York, USA.

[5] Epa.ohio.gov.gwqcp.fluoride_factsheet, Fluoride in Ohio's Ground water, Fact Sheet 2012-01, Series on Ohio's Ground water Quality, March 2012.

[6] Oiste AM (2014) Groundwater quality assessment in urban environment, Int J EnvirSci Tech, 11:2095-2102.

[7] Nagarajan R, Rajmohan N, Mahendran U, Senthamilkumar S(2010) Evaluation of groundwater quality and its suitability for drinking and agriculture use in Thanjavur city, Tamil nadu, India, Envir Monit Asse, 171: 289-308.

[8] Mattiesen H (2008) Detailed chemical analyses of groundwater as a tool for monitoring urban archaeological deposits: results from Bryggen in Gergen, J Archaeological Sci, 35: 1378-1388.

[9] Milenkovic N, Damjanovic M, Ristic M (2005) Study of heavy metal pollution in sediments from the iron gate (danuae river), serbia and Montenegro, Polish Journal of Environmental Studies, 14: 781-787.

[10] Wu JL, Zeng, HA, Yu H, Ma L, Xu, LS, Qin BQ (2012) Water and sediment quality in lakes along the middle and lower reaches of the Yangtze River, China Water Resour. Manage, 12:3601-3618. 
[11] Ikejimba CC, Sakpa S (2014) Comparative study of some heavy metals' concentrations in water and Tympanotonusfuscatusvar radula samples of Egbokodo River, Warri, Nigeria, Int J Modern Biol Re, 2: 7-15.

[12] Valavanidis A, Vlachogianni T (2010) Metal pollution in ecosystem, ecotoxicology studies \& risk assessment in the marine environment. Dept. of Chemistry, University of Athens University Campus Zografou, 15784 Athens, Greece.

[13] EPA (1986) Air quality criteria document for lead. Environmental Criteria and Assessment Office, US Environmental Protection Agency, Research Triangle Park, North Carolina.

[14] Rajappa B, Manjappa S, Puttaiah ET (2010) Monitoring of heavy metal concentration in groundwater of Hakinaka Taluk, India, Contemporary Eng Sci, 3: 183-190.

[15] Nriagu JO (1988) A silent epidemic of environmental metal poisoning? Environmental Pollution, 50: 139-161.

[16] Osibanjo O, Majolagbe AO (2012) Physicochemical quality assessment of groundwater based on land use in Lagos city, Southwest, Nigeria, Chem J, 2: 79-86.

[17] Buschmann J, Berg M, Stengel C, Winkel L, Sampson, ML, Trang, PTK, Viet PH (2008) Contamination of drinking water resources in the Mekong Delta floodplains: Arsenic and other trace metals pose serious health risks to population, EnvirInt, $34,756-764$.

[18] Fraga CG, Oteiza PI (2002) Iron toxicity and antioxidant nutrients, Toxicology, 180: 23-32.

[19] EPA (2013) Consumer Factsheet on: COPPER. Retrieved on February 26, 2016 from $\mathrm{http}: / /$ water.epa.gov/drink/contaminants/index.cfm
[20] APHA (2005) Standard methods for the examination of water and waste water, $21^{\text {st }}$ edition, American Public Health Association, Washington, DC, USA.

[21] Prasad B, Bose JM (2001) Evaluation of heavy metal pollution index for surface and spring water near a limestone mining area of the lower Himalayas, Envir Geology, 41: 183188.

[22] Backman B, Bodis D, Lahermo P, Rapant S (1997) Application of a groundwater contamination index in Finland and Slovakia, Envir Geology, 36: 55-64.

[23] Rubio B, Nombela MA, Vilas F ( 2000) Geochemistry of Major and Trace Elements in Sediments of the Ria de Vigo (NW Spain): an Assessment of Metal Pollution, Marine Pollution Bulletin, 40: 968-980.

[24] Edet AE, Offiong OE (2002) Evaluation of water quality pollution indices for heavy metal contamination monitoring. A study case from Akpabuyo - Odukpani area, Lower Cross River Basin, (southeastern Nigeria), Geo J, 57: 295-304.

[25] Wongsasuluk P, Chotpantarat S, Siriwong W, Robson M (2014) Heavy metal contamination and human health risk assessment in drinking water from shallow groundwater wells in an agricultural area in Ubon Ratchathani province, Thailand, Environ Geochem Health, 36: 169-182.

[26] Muhammed S, Shari MT, Khan S (2011) Health Risk Assessment of Heavy metals and their source apportionment in drinking water of Kohitan region, northern Pakistan. Microchem J, 98: 334-343.

[27] Nasrabadi T (2015) An Index Approach to Metallic Pollution in River Waters Int. J. Environ. Res., 9(1): 385-394. 